\title{
An Economics Appraisal of Lending Programme Organized By Women SHGs and Primary Agricultural Cooperative Banks
}

\author{
A. Malaisamy \\ Associate Professor, Agricultural Economics, Tamil Nadu Agricultural University, Tamil Nadu, India
}

Corresponding author: malaisamyecon@gmail.com (ORCID ID: 0000-0001-8822-6714)

Received: 20-03-2021

Revised: 29-05-2021

Accepted: 12-06-2021

\begin{abstract}
The present study was conducted in Madurai East and North blocks of Madurai district, Tamil Nadu to assess the performance of self-help groups and cooperatives. A total of 120 respondents were drawn from SHGs and cooperatives for this study. Being a comparatives study of SHG and Cooperative, the study would also reveal the assistance to weaker sections as compared to Cooperatives. The SHGs have helped the beneficiaries to increase their income had increased by ₹ 24176.53 , which is nearly eight times the pre-loan income. Repayment performance in SHGs is better than cooperative beneficiaries. The beneficiaries of SHGs gained additional 154.90 man-days in crop enterprise activity, 273.78 man-days in milk enterprise, and 235 man-days in petty shop business, while cooperative beneficiaries gain 35 additional man-days only in milk enterprise activity. A multiple linear regression fitted to identify factors contributing to the total income of the beneficiaries showed that the number of earning members, membership in SHGs, and ownership of milch animals significantly influenced the total income of the beneficiaries. Policy measures can be initiated for promoting the SHGs credit to help the weaker sections.
\end{abstract}

\section{HIGHLIGHTS}

(0 SHGs beneficiaries gained 154.90 additional man-days.

(0 50 percent of cooperative beneficiaries expect loan waiver.

0 Income of SHGs and cooperatives beneficiaries influenced by earning members.

Keywords: Self-help Group, co-operative, repayment, earning members per household

The due share of economic development benefits has not been reaching the poor, and the poor have not significantly contributed to the development (Preethi et al. 2014). The eligibility for assistance under poor development programs has been restricted (Balamurgan et al. 2014). The aspect of exploitation of the rural poor is well documented. In order to release the rural poor from the clutches of money lenders cooperative movement was considered the best solution (Sarumathi et al. 2011). One of the greatest strengths that remain largely untapped is the organizing potential of a united group (Srinivasan 2008). There is now increased realization of the role of SHGs in 2020 in meeting the credit needs of the poor both for consumption and productive purposes.

Under such circumstances cited above, it would be

How to cite this article: Malaisamy, A. (2021). An Economics Appraisal of Lending Programme Organized By Women SHGs and Primary Agricultural Cooperative Banks. Int. J. Soc. Sci., 10(02): 109-113.

Source of Support: None; Conflict of Interest: None क $\infty$ 
appropriate to study the lending programs organized by the NGOs and cooperatives for the rural poor. The present study highlights the impact of the cost of credit and recovery performance of loans received by SHGs and primary agricultural cooperative bank (PACB) beneficiaries. The study was conducted to assess the impact of self-help groups and cooperatives on poorer sections of the rural populations through analyzing the income performance of beneficiaries received by SHGs and PACB beneficiaries, suggesting suitable policy measures.

\section{MATERIALS AND METHODS}

Two NGOs (PRADAN and ASSEFA) which had the maximum coverage in the district were selected for the study. A simple random sampling technique selected three villages covered by each of these NGOs. In each village, fifteen beneficiaries were selected from the list of beneficiaries availing financial assistance in the SHGs functioning in the village at random. Five Primary Agricultural cooperative beneficiaries in each of the selected villages were also randomly selected. The ultimate sample size was 120 beneficiaries, including 45 beneficiaries from SHGs organized by PRADAN and 45 beneficiaries from SHGs organized by ASSEFA, and 30 beneficiaries from Cooperatives.

Multiple regression analysis was carried out to estimate and compare total annual income and overdue position of SHGs with PACBs beneficiaries. For estimating the factors influencing the annual income of the beneficiaries, a number of earing members per household, education level of respondents in years of schooling, a dummy variable to represent the membership of SHGs, a dummy variable to represent the ownership of land, and another dummy variable to represent the ownership of milch animals. The annual income was specified as the dependent variable.

General form of the Linear equation was represented by,

$$
Y=a_{0}+a_{1} x_{1}+a_{2} x_{2}+a_{3} x_{3}+a_{4} x_{4}+a_{5} x_{5}+e
$$

Where,

$Y=$ total income ('000 of ₹) ; $x 1=$ number of earing members per household $x_{2}=$ education level of respondents in years of schooling $x_{3}=$ dummy for membership of SHGs if SHG member $=1$; otherwise $=0$

$x_{4}=$ dummy for the ownership of land if owner of land $=1$; otherwise $=0$

$x_{5}=$ dummy for the ownership of milch animal if owner of milch animal $=1$; otherwise $=0$

$e=$ Stochastic error term

\section{RESULTS AND DISCUSSION}

The data collected from the sample respondents were analyzed with reference to the specific objectives of the study. The results are presented and discussed here. The present study focused attention on the impact of SHGs on the living conditions of their beneficiaries' living conditions compared to Cooperative beneficiaries, problems faced by the beneficiaries in availing the loans, and their solutions to solve them.

\section{Changes in the Asset Value of Beneficiaries}

In order to have a perspective of comparison of changes in income and employment, changes in asset position after the acquisition of loan are to be analyzed for both the categories. Changes in the asset position of beneficiaries were furnished in Table 1.

It could be inferred from the table that in the case of SHG beneficiaries, perceptible changes had taken place in all the assets. Land and livestock have been added to the households in which they were previously absent. Cattle shed have been constructed afresh. Improvements in dwelling houses and the acquisition of additional household durable assets were recorded. Thrift, a much sought for aim by the SHG, in the form of deposits in saving bank account, is recorded after availing of the benefit through the SHGs. A comparison with the cooperatives was attempted with reference to current year borrowing, and positive addition were noted in the livestock value, durable household assets, and deposit in saving bank account. The additional assets acquired by the SHG beneficiaries ere much higher than the beneficiaries of cooperatives during the year. 
An Economics Appraisal of Lending Programme Organized By Women SHGs and Primary Agricultural Cooperative Banks

Table 1: Changes in Asset Position of Beneficiaries Households (Rupees/household)

\begin{tabular}{|c|c|c|c|c|c|c|c|}
\hline \multirow{2}{*}{ S1. No. } & \multirow{2}{*}{ Particulars } & \multicolumn{3}{|c|}{ Women SHGs } & \multicolumn{3}{|c|}{ Cooperative Banks } \\
\hline & & Pre Loan & After Loan & Change & Pre Loan & After Loan & Change \\
\hline 1 & Physical Assets & & & & & & \\
\hline (a) & Land & 0.00 & 10233.33 & 10233.33 & 50000 & 50000 & 0.00 \\
\hline (b) & Dwelling house & 10225.76 & 45987.43 & & & & \\
\hline (c) & Cattle shed & & 5476.00 & 5476.00 & 12678.00 & 12678.00 & 0.00 \\
\hline 2 & Cows and Calves & & 25765.19 & 25765.19 & 45321.96 & 72765.29 & \\
\hline 3 & Sheep & & 1573.14 & 1573.14 & 9874.73 & 24095.51 & \\
\hline 4 & Poultry & 1284.86 & 1512.40 & & 2347.71 & 3265.31 & \\
\hline 5 & $\begin{array}{l}\text { Household Durable } \\
\text { Assets }\end{array}$ & 3749.12 & 9093.17 & & 39872.19 & 72840.10 & \\
\hline 6 & $\begin{array}{l}\text { Deposit in saving bank } \\
\text { account }\end{array}$ & & 5281.00 & 5281.00 & 12984.82 & 37521.93 & \\
\hline
\end{tabular}

Table 2: Gross Income of the Beneficiaries (Rupees per household)

\begin{tabular}{llllll}
\hline \multirow{2}{*}{ S1. No. } & \multirow{2}{*}{ Source of Income } & \multicolumn{2}{c}{ SHGs } & \multicolumn{2}{c}{ Cooperatives } \\
\cline { 3 - 6 } & & Pre loan & After Loan & After Loan & 25734.12 \\
\hline 1 & Crop Income & 1258.33 & 11186.83 & 20623.76 & 9989.06 \\
2 & Livestock Income & 2346.56 & 14052.51 & 9062.12 & - \\
\hline Total & Petty Shop Income & 625.00 & 2077.08 & - & $\mathbf{2 9 6 8 5 . 8 8}$ \\
\hline
\end{tabular}

Table 3: Employment Level of Beneficiaries of SHGs and Cooperatives (mandays/year)

\begin{tabular}{llllllll}
\hline \multirow{2}{*}{ S1. No. } & \multirow{2}{*}{ Source } & \multicolumn{3}{c}{ SHGs } & \multicolumn{3}{c}{ Cooperatives } \\
\cline { 3 - 8 } & & Pre Loan & After L & Additional & PL & AL & Additional \\
\hline 1 & Crop & 125.25 & 280.15 & 154.90 & 270 & 270 & 365 \\
2 & Milk & 91.22 & 365.00 & 273.78 & 270 & - & - \\
3 & Petty Shop & 125.00 & 360.00 & 235.00 & - & - & - \\
\hline
\end{tabular}

\section{Gross Income}

An analysis of the gross income of the households of the SHGs and cooperatives from different sources would reveal the difference in the financial status of the two categories of beneficiaries. Estimates of income generated through different activities per household of SHG and Co-operatives beneficiaries are presented in Table 2.

A perusal of the above table showed that the beneficiaries of SHGs stood o grater gain after acquiring the loan by ₹ 24176.53 per household. The important factors that have contributed for this increase were the acquisition of land, milch animals, and the opening of the petty shop. Regarding the beneficiaries of cooperatives the gross annual income increased by ₹ 6037.30 per annum after acquiring the loan assistance.

\section{Changes in Employment Position}

The employment positions of the beneficiaries per household in the different activities before and after availing of credit are presented in Table 3.

It could be seen from the table that the crop production and milk enterprise generated employment of 154.9, 273.78 additional man-days for SHG beneficiaries, while 
Table 4: Reasons for non-repayment and Irregular Repayment of Loan

\begin{tabular}{llllll}
\hline \multirow{2}{*}{ S1. No. } & Reasons & \multicolumn{2}{c}{ SHGs } & \multicolumn{2}{c}{ Co-operative } \\
\cline { 3 - 6 } & & Frequency & Percentage & Frequency & 27.73 \\
\hline 1 & Crop failure & 4 & 33.33 & 5 & 16.67 \\
2 & Family expenditure and prior & 8 & 66.67 & 3 & 50.00 \\
3 & commitments & - & - & 9 & 5.55 \\
4 & Expectation of waiver & - & - & 1 & $\mathbf{1 8}$ \\
\hline Total & Purchase of assets & $\mathbf{1 2}$ & $\mathbf{1 0 0 . 0 0}$ & & $\mathbf{1 0 0 . 0 0}$ \\
\hline
\end{tabular}

only milk enterprise generated additional employment of 35 man-days for cooperative beneficiaries. The petty shop business generated 235 additional man-days of employment.

\section{Factors Influencing Total Income}

To study the factors influencing total income of the beneficiaries the following variables were identified as likely causes namely number of earing members per household, educational level of respondent, membership are otherwise SHG, ownership land, ownership of milch animal. Based on the scrutiny of the scatter diagram, a linear multiple regression equation was estimated as specified below:

$$
\begin{aligned}
& Y=9379.7539+2502.1303 \times 1^{* *}+219.3269 \times 2^{\mathrm{NS}}+30968.5156 \times 3^{* *} *-5625.5488 \times 4^{\mathrm{NS}}+14360.3428 \times 5^{* *} \\
& \begin{array}{lllll}
(2605.1526) & (626.0999) & (4958.5059) & (4197.8623) & (3842.3918)
\end{array}
\end{aligned}
$$

$R 2=0.6277 ; N=120 ; F=11.1142 ;$ NS-Non Significant; ${ }^{* *}$ - Significant at one per cent

The multiple regression coefficients 0.62 indicated that 63 percent variation in total income was explained by the variable included in the function. The function as a whole was significant at a one percent probability level. The signs of regression coefficient were in confirmation with a priori expectation for all explanatory variables except the ownership of land, for which it was statistically non-significant. The co-efficient for the educational level of respondents though positive, was not significant. An increase in the number of earning members significantly increased the total income, and an increase in one earning member will increase the total income by ₹ 2502.13. The members of SHGs had significantly realized higher total income than nonmembers by
30968.51. The rearing of milch animals increased the total income by ₹ 14360.32 over the livestock non-rearing members. Thus the numbers of earning members per household, membership of SHG, ownership of milch animals were the variables found to influence the total income of the beneficiaries significantly.

\section{Reasons for non Repayment and Irregular Repayment of Loan}

Irregular repayment caused the accumulation of debt and increased the overdue position of lending agencies. This affected viability and future lending activities. Moreover, this affected hot only irregular repayers but also deprived of future credit needs of the regular repayers. The reason for irregular repayment of a loan by the beneficiaries was assessed are furnished in Table 4 .

The reason stated for non-repayment and irregular repayment by 50 percent of beneficiaries of cooperative society was the expectation of loan waiver, followed by crop failure and family expenditure, and other prior commitments, whereas among SHG beneficiaries, the primary reason was family expenditure and other commitments (66.67) followed by crop failure (33.33 percent)

\section{CONCLUSION}

Income and employment of beneficiaries of SHGs had shown significant as compared to beneficiaries of cooperatives. Thus SHGs are seen to be successful in assisting in the weaker section, and the members also find SHGs most convenient in access as they did not face any problem in obtaining credit. Policy measures can 
be initiated for promoting he SHGs to help the weaker sections.

\section{REFERENCES}

Balamurgan, P. and Selvaraj, D.A. 2014. Microfinance and poverty alleviation: an analysis with SHGs contribution. Int. J. Res. Manag. Pharm., 3(1): 7-14.

Ramath, P. and Preethi 2014. Microfinance in India- for poverty reduction. Int. J. Res. Dev. Manag. Rev., 2(4): 20-23.
Sarumathi, S. and Mohan, K. 2011. Role of microfinance in women empowerment: an empirical study in Pondicherry region rural SHGs. J. Manag. Sci., 1(1): 1-10.

Srinivasan, N. 2009. Microfinance India: state of the sector report, 2009. Sage Publications India Pvt Ltd, New Delhi, India. 
